\title{
VARTOTOJŲ PRISIJUNGIMO PRIE DIDŽIAUSIŲ EUROPOS ORO LINIJU BENDROVIŲ LOJALUMO PROGRAMŲ SĄLYGOS
}

\author{
Neringa VILKAITĖ-VAITONĖ, Vytenis ŠALKAUSKIS* \\ Vilniaus Gedimino technikos universitetas, Verslo vadybos fakultetas, Vadybos katedra, \\ Sauletekio al. 11, LT-10223, Vilnius, Lietuva \\ "El.paštas vytenis.salkauskis@stud.vgtu.lt
}

\begin{abstract}
Santrauka. Straipsnyje nagrinėjamas lojalumo programų klausimas aviacijos sektoriuje. Pateikiama bendra lojalumo programos samprata, apžvelgiami ịvairūs jų tipai, nagrinėjamos prisijungimo prie lojalumo programų sąlygos. Naudojama mokslinès literatūros, lyginamoji analizè. Užsibrěžiamas tyrimo tikslas - išnagrinèti situaciją didžiausiose Europos oro linijų bendrovėse vartotojų lojalumo programų klausimu. Dėmesys skiriamas šių programų paplitimui, tipui bei prisijungimo sąlygoms minètose oro linijų bendrovėse. Naudojama turinio analizè. Tyrimo rezultatai atskleide, jog beveik visos didžiausios Europos oro linijų bendrovès naudoja lojalumo programas, iš kurių didžioji dalis yra hierarchinio tipo, o pagrindinės dominuojančios sąlygos prisijungimui vartotojo amžius (minimalus amžius - 2 metai, kai atsakomybę už vaiką prisiima tèvai) ir statusas (leidžiama prisijungti tik fiziniams asmenims). Dalis oro linijų bendrovių prisijungimui prie lojalumo programų taiko ir teritorinius, finansinius ar kitokio pobūdžio apribojimus. Tai leidžia daryti išvadą, kad bendrovès atsakingai žvelgia ị vartotojus ir ịvertina jų polinkị išlikti lojaliais ilgesnị laikotarpị.
\end{abstract}

Reikšminiai žodžiai: lojalumo programos, prisijungimo prie programų sąlygos, didžiausios Europos oro linijų bendrovès, lojalumo programų vartotojai, aviacijos sektorius, lojalumo programų tipai.

\section{Ivadas}

Tyrimo aktualumas. XXI a. aviacijos sektoriui būdinga intensyvi plètra. Kelionėms oru įsitvirtinus kaip sparčiausioms ir saugiausioms, lyginant su kitais keliavimo būdais, stebimas aviacijos sektoriaus progresas. Stiprejantys vartotojų poreikiai kelionèms didina ir kelionių oro transportu pasiūlą, kas intensyvina ir konkurenciją tarp paslaugu teikèjų. Pasaulyje veiklą vykdo nuo 5000 iki 5500 oro vežějų. Kasdien jie ịvykdo daugiau nei 100 tūkstančiu skrydžių, o 2018 m. visame pasaulyje oru buvo pervežta beveik 4,5 milijardo keleivių (Cox, 2018). Šie duomenys rodo, kad konkurencija tarp atskirų oro linijų - labai intensyvi. Tokios intensyvios konkurencijos sąlygomis prasmę igyja vartotojų lojalumo programos - viena iš marketingo priemonių, paplitusi nuo XX a. devintojo dešimtmečio ịvairiuose verslo sektoriuose. Ši priemonė pasitelkiama siekiant pritraukti naujų vartotojų, vèliau - paskatinti esamus vartotojus ir toliau pirkti prekes ar paslaugas, siekiant išlaikyti konkurencini pranašumą rinkoje. Ne išimtis yra ir aviacijos sektorius. Dažna oro linijų bendrovè taiko vartotojų lojalumo programą, kuria siūlo ịvairias naudas vartotojui, ịvykdžiusiam tam tikrus bendrovės numatytus uždavinius (pavyzdžiui, keliauti su bendrovès orlaiviais bent 10 kartụ). Kita vertus, reikia ịvertinti tai, kad ị lojalumo programas ne visada galima lengvai, iš karto įsitraukti (tapti jų nariu). Kai kuriais atvejais vartotojas turi pasiekti tam tikrą iš anksto nustatytą kiekị nuopelnų, pavyzdžiui, numatytą pirkimų skaičių, kad galètų prisijungti prie norimos lojalumo programos. Esant itin plačiai oro liniju bendrovių taikomų lojalumo programų įvairovei ir dideliam jų paplitimo mastui, prisijungimo prie šiu programų sąlygų analizè tampa svarbi ir savalaikè. Tikimasi, kad oro linijų bendrovių patirties šioje srityje analizè sudarys prielaidas identifikuoti sudètingiausiai ir paprasčiausiai vartotoju peržengiamus barjerus, siekiant prisijungti prie lojalumo programos.

Tyrimo naujumas. Vartotojų lojalumo programos ir prisijungimo prie šių programų sąlygos gana aktyviai tyrinètos užsienio šalių mokslinèje literatūroje (Bombaij ir Dekimpe, 2019; Brashear-Alejandro et al., 2016; Nastasoiu ir Vandenbosch, 2019). Démesio sulaukè ir oro linijų bendrovių lojalumo programos (de Jong et al., 2019; Martín et al., 2011). 2018 m. didžiausių Europos oro linijų bendrovių pagal pervežamą keleivių kieki lojalumo programu sąlygos iki šiol netyrinètos, neatlikti lyginamieji vertinimai tarp skirtingų bendrovių prisijungimo prie lojalumo programų sąlygų.

Tyrimo problema. Aviacijos sektoriaus dinamiškumas kelia poreikị oro linijų bendrovėms reguliariai nagrinèti ịvairius savo lojalumo programų aspektus. Prisijungimo sąlygos, greta siūlomų naudų, terminų, partnerystès 
galimybių, yra vienas iš šių aspektų. Tyrimo problema formuluojama tokiais klausimais: koks vartotojų lojalumo programų paplitimas didžiausiose Europos oro linijų bendrovėse? Kokios sąlygos keliamos vartotojams, norintiems prisijungti prie lojalumo programų? Kokios sąlygos dominuoja?

Tyrimo objektas - prisijungimo prie didžiausių Europos oro linijų bendrovių vartotojų lojalumo programų sąlygos.

Tyrimo tikslas - išnagrinėti vartotojų prisijungimo prie oro linijų bendrovių lojalumo programų sąlygas. Tyrimo tikslui igyvendinti iškelti tokie $u z ̌ d a v i n i a i$ :

1. Atskleisti vartotojų lojalumo programų sampratą.

2. Išanalizuoti nuopelnų, suteikiančių vartotojui galimybę prisijungti prie lojalumo programos, ịvairovę.

3. Atlikti didžiausių Europos oro linijų taikomų prisijungimo prie vartotojo lojalumo programų sąlygų analizę.

Tyrimo metodai: mokslinès literatūros analizè, lyginamoji analizè, turinio analizè, apibendrinimas.

\section{Vartotojų lojalumo programų samprata ir struktūra}

Vartotojų lojalumo programos kaip marketingo priemonè imtos taikyti XXa. pabaigoje. Pirmaja modernia vartotojų lojalumo programa laikoma „AAdvantage“ - lojalumo programa, kurią sukūrè Jungtinių Amerikos Valstijų (JAV) oro linijų bendrovė „American Airlines“ (Hua et al., 2018). Vystantis naujoms technologijoms vartotojų lojalumo programos ịgavo dideli populiarumą ir ėmé plisti ịvairiuose verslo sektoriuose. Vienas iš jų apgyvendinimo (viešbučių sektorius), kuriame pirmąją lojalumo programą pasiūlè bendrové „Marriott" 1983 metais, labai panašią ị tuometines oro linijų bendrovių siūlomas lojalumo programas (Koo et al., 2020).

Vartotojų lojalumo programos terminas gali būti traktuojamas labai ịvairiai. Dalis lojalumo programų apibrèžimų, rastų mokslinèje literatūroje, pateikti 1 lentelëje.

1 lentelè. Vartotojų lojalumo programos apibrèžimai (parengta straipsnio autorių)

\begin{tabular}{|l|l|}
\hline \multicolumn{1}{|c|}{ Autoriai } & \multicolumn{1}{c|}{ Apibrèžimas } \\
\hline $\begin{array}{l}\text { Dorotic, Bijmolt ir Verhoef } \\
\text { (2012) }\end{array}$ & $\begin{array}{l}\text { Ilgalaikè skatinamoji programa, kuri vartotojams siūlo naudas už pirkimą, taip didinant } \\
\text { jų lojalumą }\end{array}$ \\
\hline Evanschitzky et al. (2012) & $\begin{array}{l}\text { Marketingo pastangos (priemonės), kurios padeda užmegzti lojalų ryšị tarp } \\
\text { organizacijos ir pelningų vartotojų }\end{array}$ \\
\hline Garzon ir Taylor (2016) & $\begin{array}{l}\text { Programos, organizacijų naudojamos, siekiant suteikti vartotojams svarbumo ir/ar } \\
\text { buvimo specialiu pojūti }\end{array}$ \\
\hline $\begin{array}{l}\text { Chaudhuri, Voorhees ir Beck } \\
(2019)\end{array}$ & $\begin{array}{l}\text { Marketingo strategijos priemonè, kurios tikslas yra abipusės naudos tarp organizacijos ir } \\
\text { vartotojo siekimas per tarpusavio santykių gerinimą }\end{array}$ \\
\hline
\end{tabular}

Dorotic, Bijmolt ir Verhoef (2012) apibrěžime akcentuojamas lojalumo programos tęstinumas: siūlomos naudos vartotojui ir vartotojų lojalumo didinimas vyksta ilgalaikèje perspektyvoje. Kitame apibrèžime (Evanschitzky et al., 2012) akcentuojamas lojalus ryšys tarp organizacijos ir vartotojų, kurie turi pelno potencialą. Lojalumą bei tarpusavio santykių gerinimą lojalumo programomis pabrèžia ir kiti autoriai (Chaudhuri et al., 2019). (Garzon ir Taylor, 2016) pateikia ir šiek tiek kitokią apibrěžti, akcentuojančią suteikiamą svarbumo jausmą vartotojui, tampant tam tikros programos dalimi. Šie pavyzdžiai pagrindžia mintị, kad vienareikšmiškai apibūdinti vartotojo lojalumo programas ir suteikti joms vienintelę apibrěžti yra sudètinga (ir tikriausiai neịmanoma). Pastebėtinas bendras šių apibrēžimų bruožas - lojalumo programos neabejotinai yra marketingo priemonė. Dar viena vartotojų lojalumo programų apibrèžtis nusakoma taip - tai organizacijos produkto pardavimų didinimo ir tarpusavio santykių su vartotojais gerinimo strategijos sprendimas, ypatingą dèmesị skiriant abipusès naudos gavimui bei vartotojo lojalumo didinimui, už pirkimą suteikiant įvairius paskatinimus.

Kaip teigiama mokslinejje literatūroje (Lo et al., 2017; Gambarov et al., 2017), pagrindiniai bendrovès santykių su vartotoju vertinimo kriterijai (charakteristikos) yra pasitikejjimas, pasitenkinimas ir įsipareigojimas. I šias charakteristikas įmonès turi atsižvelgti vystydamos savo lojalumo programas, išpildydamos vartotojų lūkesčius. Pasitikejjimas - šalies pasiryžimas pasikliauti savo mainų partneriu, kuris rodo entuziazmą pratęsti abipusius santykius. Pasitikejjimo proceso vystymas pagrịstas išankstinių šalių lūkesčių nusistatymu ir vèlesniu šių lūkesčių progreso ịvertinimu. Pasitenkinimas - ilgalaikių bendradarbiavimo patirčių su partneriu vertinimas, kuris tiesiogiai priklauso nuo bendrovės veiklos sėkmingumo jos gyvavimo laikotarpyje. Vartotojo pasitenkinimas atspindi jo emociją arba jo požiūrį i esamus rezultatus, lyginant su išsikeltais tikslais. İsipareigojimas - troškimas susikurti stabilius santykius su mainų partneriu, suvokiant, kad bendradarbiavimas yra gyvybiškai svarbus užtikrinant maksimalias pastangas jam išlaikyti. Šios charakteristikos yra tiesiogiai priklausomos nuo siūlomų lojalumo programų sąlygų bei jų taikymo (pavyzdžiui, paprastesnès sąlygos prisijungimui prie lojalumo programos vartotojui suteikia didesni pasitenkinimą, ir atvirkščiai). 
Nagrinejjant vartotojų lojalumo programos tipus mokslinèje literatūroje, randama ne viena tipologija. Bendru atveju, jos gali būti vieno lygmens arba keleto lygmenų (hierarchinès) (Colliander et al., 2016), kaupiamosios arba nekaupiamosios (Skačkauskienè ir Vilkaitè-Vaitonė, 2017). Vieno lygmens lojalumo programa nurodo bendras konkrečias sąlygas ar veiksmus, kuriuos reikia ịvykdyti norint prisijungti prie programos. Atitinkamai keleto lygmenų lojalumo programos kiekvieno lygio pasiekimui nurodo atskiras sąlygas. Esant kaupiamajai lojalumo programai, vartotojas, ịsigydamas bendrovès produktą, gauna vadinamųjų lojalumo taškų, kurių sukaupęs atitinkamą sumą, gali išsikeisti i bendrovès siūlomas naudas.

Pasak (Skačkauskienė ir Vilkaitè-Vaitonė, 2017), bazinè vartotojų lojalumo programos sandara susideda iš tam tikrų elementų.

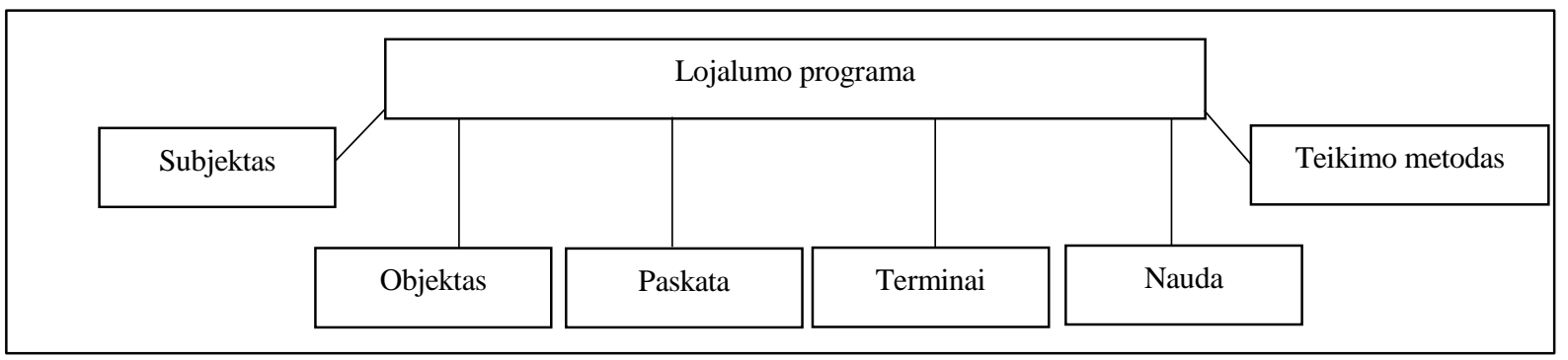

1 paveikslas. Vartotojų lojalumo programų bazinè sandara

Kaip matyti iš 1 paveikslo, lojalumo programą sudaro tokie elementai: subjektas, objektas, paskata, terminai, nauda, teikimo metodas. Kiekvienas jų yra svarbus efektyviam lojalumo programos funkcionavimui, elementai papildo vieni kitus.

Subjektas - tai vartotojas, kuris ir yra pagrindinè varomoji lojalumo programos jèga. Pavyzdžiui, JAV apie 90 proc. visų vartotojų paslaugų sektoriuje yra bent vienos lojalumo programos nariais (So et al., 2015). Subjektas gali gauti ir naudotis siūlomais įmonių atlygiais, numatytais lojalumo programoje.

Antrasis programos elementas - objektas, kuriuo apibūdinamos sąlygos (nuopelnai), kurias įvykdęs vartotojas tampa programos nariu. Iprastai viena iš būtinujjų sąlygų buvo vartotojo noro dalyvauti programoje išreiškimas, tačiau kai kurios organizacijos elgèsi ne visai teisètai ir įtraukdavo vartotojus i savo lojalumo programas be jų sutikimo ar net jiems to nežinant. Nuo 2018 m. gegužès 25 d. įsigaliojus Europos Sajungos reglamentui - Bendrasis duomenu apsaugos reglamentas - BDAR (angl. GDPR) ịvedė naujas taisykles, pagal kurias bet kuri organizacija, norėdama kaupti ir panaudoti vartotojų duomenis, privalo gauti jų sutikimą (IT Governance ir European Union, 2017).

Paskata lojalumo programoje padeda identifikuoti lojaliausius vartotojus. Šị elementą galima apibūdinti kaip organizacijos tam tikrus skiriamus lojalumo taškus vartotojui už pakartotinị produktų ar paslaugų ịsigijimą. Paskatų pagrindas vartotojams yra suteikiamos programos naudos (Skačkauskienė ir Vilkaitė-Vaitonè, 2017).

Kitas elementas - terminai, nusako lojalumo taškų galiojimo trukmę programoje. Vartotojų lojalumo programų privalumas yra esamų išlaidų nukreipimas ị ateitị, siūlant ne momentines, o naudas, kurias galima atsiimti vèliau (Breugelmans ir Liu-Thompkins, 2017). Nepaisant to, neišnaudoti neterminuoto galiojimo taškai gali tapti svarbia problema organizatoriui (pavyzdžiui, taškai imami naudoti vienu metu, o ne ilguoju laikotarpiu, kas organizacijai sukelia dideles momentines išlaidas), todèl priklausomai nuo organizacijos strateginių planų, tikslinga ivertinti, kokio termino lojalumo programa funkcionuos racionaliausiai.

Suteikiama nauda vartotojui taip pat yra vienas pagrindinių elementų kartu su subjektu. Subjektas kartu su nauda yra pagrindiniai lojalumo programos elementai, o likę elementai - papildomos priemonès, skirtos sąveikai tarp šių elementų užtikrinti. Nauda, arba atlygis, gali būti dviejų tipų - hedonistinis (atskiras įmonès vartotojo pripažinimas, išskirtinè komunikacija, suteikiamos unikalios paslaugos) ir taikomasis (kuponas, nuolaida, dovana ir pan.). Taikomojo tipo atlygis gali būti atsiimamas iš karto, panaudojant lojalumo taškus, arba vẻliau, ilgalaikèje perspektyvoje (Skačkauskienè ir Vilkaitè-Vaitonè, 2017). Paradoksalu, bet ịprastai menkai suinteresuoti užmegzti tvirtus ryšius su organizacija vartotojai yra labiau linkę atsiimti momentinius atlygius, o ne ištęstinius, net jeigu momentinių atlygių vertè yra žemesnè (Dorotic et al., 2012). Todèl labai svarbu tinkamai motyvuoti vartotoją ilgalaikiam bendradarbiavimui su organizacija.

Paskutinis iš pateiktų elementų - teikimo metodas - nusako, kokiu būdu organizacija siūlo vartotojams atsiimti naudas, t. y. su partneriais, ar be. Šiuo metu stebimi platūs partnerysčių panaudojimo mastai. Viešbučiai siūlo įvairiais lojalumo programas, tačiau gana sudėtinga jas padaryti unikalias, išskirtines iš kitu programų, todèl kai kurios apgyvendinimo įstaigos bendradarbiauja su organizacijomis iš kitų sektorių. Tokiu būdu išplečiama naudų įvairové, o vartotojas tampa labiau lojalus viešbučiui (Yoo et al., 2018). Tikètina, kad partneryste grịstas naudų teikimo metodas padeda įmonèms būti labiau konkurencingoms šiuolaikinėse rinkose. 
Apibendrinant lojalumo programų sampratos ir struktūros analizę, galima teigti, kad per pastaruosius kelis dešimtmečius lojalumo programos įsitvirtino daugelyje verslo sektorių kaip sėkminga ir plačiai taikoma marketingo priemonè. Naujai besikuriančioms organizacijoms derètų skirti dėmesio pagrịstos ir organizacijos strateginius siekius atitinkančios lojalumo programos struktūros parinkimui.

\section{Lojalumo programų nuopelnų, suteikiančių vartotojui galimybę prisijungti prie lojalumo programos, gerosios patirties analizè}

Tyrimas sukoncentruotas ị vieną iš lojalumo programų elementų - objektą. Tai, šiuo atveju, yra prisijungimo prie lojalumo programų nuopelnai - sąlygos, kurias ịvykdęs vartotojas tampa lojalumo programos nariu. Siekiant atskleisti nuopelnų, suteikiančių vartotojui galimybę prisijungti prie lojalumo programos, ịvairovę, analizuojamos ivvairių verslo sektorių lojalumo programų prisijungimo sąlygos.

Dėmesio vertas apgyvendinimo sektoriuje veikiančios „MGM Resorts International“ pavyzdys. İmonė prie savo lojalumo programos „M Life“ suteikia galimybę prisijungti visiems asmenims, kurie atitinka šias pagrindines sąlygas: 1) asmuo yra bent 21 metų amžiaus; 2) asmuo yra fizinis (ne juridinis) (MGM Resorts, 2019). Jie gali tapti lojalumo programos nariais susikūrę nemokamą narystės paskyrą. Lojalumo programa yra hierarchinės (keleto lygmenų) struktūros (Mimouni Chaabane ir Pez, 2017), kurioje renkant specialius lojalumo taškus galima pasiekti aukštesnius programos lygius, suteikiančius didesnes naudas vartotojui. Taškų rinkimas apima vartotojo išlaidas viešbučio, maitinimo, pramogų, sveikatingumo (SPA) paslaugoms bei laimėjimus lošimuose.

Kita apgyvendinimo kompanija „Marriott International“ prisijungimui prie savo lojalumo programos „Marriott Bonvoy“ taiko kiek kitokias pagrindines prisijungimo sąlygas: 1) asmuo nėra Kubos, Irano, Šiaurès Korejos, Sudano, Sirijos ar Krymo regiono gyventojas; 2) asmuo šiuo metu nėra lojalumo programos dalyvis; 3) asmuo prieš tai nebuvo pašalintas iš programos (Marriott, 2019). Programoje paprasčiausio statuso igijimas yra nemokamas kaip ir „M Life“ lojalumo programoje, tačiau aukštesnių statusų pasiekimas yra pagrisstas nakvynių skaičiumi per kalendorinius metus. Pavyzdžiui, pirmajam aukštesniajam statusui igyti reikia įsigyti bent 10 nakvynių (neterminuotu laikotarpiu), o aukščiausio, elitinio statuso pasiekimui - issigyti bent 100 nakvyniu ir išleisti bent $20000 \mathrm{JAV}$ dolerių per vienerius kalendorinius metus.

Maitinimo sektoriuje veikianti organizacija „Starbucks“ savo lojalumo programoje „Starbucks Rewards“ taiko porą esminių sąlygų, norintiems prisijungti: 1) vartotojas turi būti bent 13 metų; 2) registracijos metu vartotojas turi būti JAV arba Puerto Riko sandraugos gyventojas. Vartotojai, atitinkantys šias sąlygas, gali tapti lojalumo programos nariais nusipirkdami realią „Starbucks" kortelę, arba atsisiųsdami programėlę ir užregistruodami virtualią kortelę (Starbucks, 2019). Pati lojalumo programa yra vieno lygmens, kaupiamojo tipo. Vartotojas, atsiskaitydamas specialia „Starbucks“ kortele arba programėle, kaupia taškus (šiuo atveju - „žvaigždes“), už kuriuos vèliau gali pasirinkti kavą su priedais ar papildomą užkandį. Pavyzdžiui, už kiekvieną išleistą JAV dolerị vartotojui suteikiamos dvi ,Žvaigždès“, o surinkus 50 ,Žvaigždžių“, vartotojas gauna kruasaną dovanų.

Prekybos sektoriuje veikiantis, turizmo prekių platintojas „Recreational Equipment, Inc“ siūlo kitokio tipo vartotojų lojalumo programą, nei anksčiau minėtuose sektoriuose pateikti pavyzdžiai. Lojalumo programa „REI Co-op“ turi porą pagrindinių prisijungimo sąlygų: 1) asmuo turi būti ne jaunesnis nei 13 metų; 2) už narystę sumokamas vienkartinis 20 JAV dolerių mokestis (REI, 2019). Programa neturi hierarchinès struktūros, visi programos dalyviai gauna vienodas naudas.

Grožio prekių rinkoje veikianti „Sephora“ vartotojų lojalumo programoje „Beauty Insider“ taiko hierarchinę struktūrą su dviejomis pagrindinėmis prisijungimo sąlygomis: 1) asmeniui turi būti bent 13 metų; 2) asmuo yra teisètas Kanados arba JAV gyventojas (Sephora, 2019). Vartotojai gali nemokamai prisijungti, paprašydami lojalumo kortelès parduotuveje ir tapdami žemiausio lygio nariu, o išleisdami tam tikras sumas per kalendorinius metus, pasiekti aukštesnès pakopos narystę, pavyzdžiui, „VIB“. Aukštesnès pakopos narystė suteikia prieigą prie vertingesnių naudų.

Aviacijos sektoriuje vartotojų lojalumo programos yra labai paplitusios. Anksčiau šiame straipsnyje jau minèta oro linijų bendrovė „American Airlines“, visuomenei pristačiusi pirmają modernią vartotojų lojalumo programą „AAdvantage“, ją tobulina ir vysto iki pat šių dienų. Programa grindžiama „mylių“ valiuta, kurias galima gauti įvairiais būdais - skrendant, naudojantis bendrovès partnerių paslaugomis, perkant (pavyzdžiui, per juodojo penktadienio akciją buvo siūloma įsigyti didesnį „mylių“ skaičių už mažesnę sumą). Vartotojui suteikiama pasirinkimo laisvė, kaip naudotis lojalumo programos teikiamomis naudomis - už sukauptas „mylias“ galima pasinaudoti bendrovès bei partnerių siūlomomis naudomis, o keliaujant dažniau - siekti elitini statusą suteikiančių reikalavimų ịvykdymo (hierarchinè struktūra). Prisijungimui prie programos rasta tik viena esminè sąlyga - asmuo turi būti fizinis, individualus, o nariu tampama susikūrus nemokamą narystės paskyrą (American Airlines, 2019).

Analizuotų lojalumo programų prisijungimo sąlygų suvestinè pateikta 2 lentelèje.

Pristačius skirtinguose verslo sektoriuose veikiančių organizacijų lojalumo programas, matyti, kad prisijungimui prie jų populiariausios, dominuojančios keliamos sąlygos yra vartotojo amžiaus apribojimas (narys turi būti ne jaunesnis nei 13 metų), vartotojas turi išreikšti savo norą dalyvauti programoje, užregistruodamas nario paskyrą ar įsigydamas programos kortelę. Beveik visuose sektoriuose yra ịvesti teritoriniai narystès ribojimai. Analizès 
metu identifikuota ir mokama lojalumo programa prekybos sektoriuje, turinti vienkartinį $20 \mathrm{JAV}$ dolerių ịstojimo mokestį. Pastebėta, kad išskirtinị populiarumą ir paplitimą turi hierarchinès struktūros lojalumos programos. Toks pasirinkimas tikslingas, siekiant nuoseklaus ryšių tarp organizacijos ir vartotojo stiprinimo.

2 lentelè. Prisijungimo prie lojalumo programų sąlygų analizès suvestinè (parengta straipsnio autorių)

\begin{tabular}{|c|c|c|c|}
\hline Sektorius & Organizacija & Lojalumo programa & Pagrindinès prisijungimo sąlygos \\
\hline \multirow[b]{2}{*}{ Apgyvendinimo } & $\begin{array}{l}\text { MGM Resorts } \\
\text { International }\end{array}$ & $\begin{array}{l}\text { „M Life“, } \\
\text { hierarchinè }\end{array}$ & $\begin{array}{l}\text { 1. Asmuo yra bent } 21 \text { metų amžiaus } \\
\text { 2. Asmuo yra fizinis, individualus } \\
\text { 3. Tapimui nariu reikia susikurti nemokamą narystès paskyrą }\end{array}$ \\
\hline & $\begin{array}{l}\text { Marriott } \\
\text { International }\end{array}$ & $\begin{array}{l}\text { „Marriott Bonvoy“", } \\
\text { hierarchinè }\end{array}$ & $\begin{array}{l}\text { 1. Asmuo nėra Kubos, Irano, Šiaurès Korèjos, Sudano, } \\
\text { Sirijos ar Krymo regiono gyventojas } \\
\text { 2. Asmuo šiuo metu nėra šios programos narys } \\
\text { 3. Asmuo prieš tai nebuvo pašalintas iš šios programos } \\
\text { 4. Tapimui nariu reikia susikurti nemokamą narystės paskyrą }\end{array}$ \\
\hline Maitinimo & Starbucks & $\begin{array}{l}\text { „Starbucks } \\
\text { Rewards“, } \\
\text { kaupiamoji, vieno } \\
\text { lygmens }\end{array}$ & $\begin{array}{l}\text { 1. Asmuo yra bent } 13 \text { metų amžiaus } \\
\text { 2. Asmuo registracijos metu turi būti JAV arba Puerto Riko } \\
\text { sandraugos gyventojas } \\
\text { 3. Tapimui nariu reikia įsigyti realią lojalumo programos } \\
\text { kortelę arba atsisiųsti Starbucks programėlę }\end{array}$ \\
\hline $\begin{array}{l}\text { Prekybos } \\
\text { (turizmo } \\
\text { prekès) }\end{array}$ & $\begin{array}{l}\text { Recreational } \\
\text { Equipment, } \\
\text { Inc }\end{array}$ & $\begin{array}{l}\text { „REI Co-op“, } \\
\text { vienkartinio } \\
\text { mokesčio }\end{array}$ & $\begin{array}{l}\text { 1. Asmuo yra bent } 13 \text { metų amžiaus } \\
\text { 2. Tapimui nariu reikia sumokèti vienkartinị } 20 \mathrm{JAV} \text { dolerių } \\
\text { mokestị }\end{array}$ \\
\hline $\begin{array}{l}\text { Prekybos } \\
\text { (grožio prekès) }\end{array}$ & Sephora & $\begin{array}{l}\text { „Beauty Insider“, } \\
\text { hierarchinè }\end{array}$ & $\begin{array}{l}\text { 1. Asmuo yra bent } 13 \text { metų amžiaus } \\
\text { 2. Asmuo yra teisėtas Kanados arba JAV gyventojas } \\
\text { 3. Tapimui nariu reikia pasiimti nemokamą kortelę } \\
\text { parduotuvèje }\end{array}$ \\
\hline Aviacijos & $\begin{array}{l}\text { American } \\
\text { Airlines }\end{array}$ & $\begin{array}{l}\text { "AAdvantage“, } \\
\text { hierarchiné }\end{array}$ & $\begin{array}{l}\text { 1. Asmuo yra fizinis, individualus } \\
\text { 2. Tapimui nariu reikia susikurti nemokamą narystès paskyrą }\end{array}$ \\
\hline
\end{tabular}

\section{Didžiausiose Europos oro linijų bendrovėse taikomų prisijungimo prie lojalumo programos sąlygu analizè}

\subsection{Tyrimo metodika}

Tyrimo tikslas yra išnagrinèti didžiausių Europos oro linijų bendrovių taikomų prisijungimo prie lojalumo programų sąlygas. Tyrimas atliktas tokiais etapais: 1) surinkti tiesioginiai duomenys iš didžiausių Europos oro linijų bendrovių apie vartotojų lojalumo programas ir jų prisijungimo sąlygas; 2) šie duomenys išanalizuoti (turinio analizès metodu), pristatyti analizès rezultatai; 3) padarytos išvados. Tyrimu siekta rasti atsakymus i iškeltus probleminius klausimus - koks vartotojų lojalumo programų paplitimas didžiausiose Europos oro linijų bendrovėse? Kokios sąlygos keliamos vartotojams, norintiems prisijungti prie lojalumo programų? Kokios sąlygos dominuoja? Informacija imama iš oro linijų bendrovių internetinių tinklalapių.

I analizę ịtrauktos 25 didžiausios Europos oro linijos, iš kurių trys bendrovès valdo daugiau nei vieną oro linijų bendrovę. „Lufthansa Group“ priklauso 5 bendrovès (Lufthansa Group, 2019), „International Airlines Group“ priklauso taip pat 5 bendrovès (IAG, 2019), o „Air France-KLM“ priklauso 3 bendrovès (Air France-KLM, 2019). Bendras nagrinejjamų oro linijų bendrovių skaičius - 35. Bendrovių dydis vertinamas pagal jų pervežamų keleivių kiekị per metus, remiantis $2018 \mathrm{~m}$. duomenimis (Statista, 2018) bei oro linijų bendrovių interneto svetainėse esančia informacija. Duomenys turinio analizei surinkti iš oro linijų bendrovių interneto svetainių. Svetainėse ieškota siūlomų lojalumo programų sąlygų, jos lygintos tarp skirtingų bendrovių lojalumo programų.

Duomenų apdorojimui naudota programa „MS Excel“. Pirmiausia, šioje programoje parengta duomenų matrica. Siekiant patogesnès duomenų analizès, oro linijų bendrovės surūšiuotos pagal pervežtų keleivių skaičių. Tuomet nagrinètas kiekvienos oro linijų bendrovės interneto svetainės turinys, ieškant informacijos apie lojalumo programas, jų sąlygas. Nagrinèta, ar prisijungimo prie lojalumo programos sąlygose numatyti amžiaus, teritoriniai, finansiniai ar kitokio pobūdžio apribojimai. Rasta informacija užfiksuota duomenų matricoje. Surinkus duomenis, atlikti skaičiavimai, atlikta duomenų analizè.

\subsection{Tyrimo rezultatai}

Atlikto Europos oro linijų bendrovèse taikomų prisijungimo prie lojalumo programos sąlygų tyrimo rezultatai parodè, kad iš 35 analizuotų didžiausių Europos oro linijų bendrovių vartotojų lojalumo programas taiko 33 
(94,3 proc) (3 lentelè). Viena iš bendrovių, netaikančių lojalumo programos - „Flybe“. Bendrovė nutraukė ankstesnę taikytą vartotojų lojalumo programą $2019 \mathrm{~m}$. rugsejjo $20 \mathrm{~d}$. (Flybe, 2019), ir šiuo metu kurią naują lojalumo programą, kurios tiksli pradžios data nèra žinoma. Kita, lojalumo programos netaikanti bendrovė yra „Smartwings“ (Smartwings, 2019). Viena iš analizuotų bendrovių, pigių skrydžių britų bendrovẻ „easyJet" taiko dvi lojalumo programas - atvirą kasmetinio mokesčio nekaupiamają programą easyJet Plus bei uždarojo tipo, tik su pakvietimu - Flight Club programą (easyJet, 2019b). Kasmetinio mokesčio programa easyJet Plus priima naujus narius jiems sumokèjus metinị mokestị (252 eurus per metus). I gaunamas naudas ịeina privalumai, tokie kaip sėdejjimo vietos pasirinkimas, greitesnè prieiga prie apsaugos punktų ir tt. Uždarojo tipo lojalumo programa Flight $C l u b$ yra nemokama, tačiau pati bendrovè pasirenka ir atsirenka jos narius. Minimali prisijungimo prie programos sąlyga - per metus nuskrista bent 20 atgalinių skrydžių su ,easyJet“, tačiau tai nereiškia, jog sąlygą ịvykdę vartotojai garantuotai taps šios programos nariais. Vartotojai, tapę Flight Club programos nariais, gali naudotis nemokamais skrydžių datos bei maršrutų keitimais, kainų skirtumų kompensavimais (jei randamas pigesnis skrydis kitoje oro linijoje, „easyJet“ kompensuoja kainos skirtumą ir suteikia 10 proc. kainos skirtumo kuponą ateities skrydžiams).

Identifikavus oro linijų bendroves, taikančias lojalumo programas, atlikta prisijungimo prie lojalumo programos sąlygų analizè. Tyrimo rezultatai atskleidè, jog visose be išimties bendrovių lojalumo programų sąlygose yra nurodoma, kad prisijungti gali tik fizinis asmuo, juridiniams asmenims tai draudžiama. Taip pat visose lojalumo programose reikia užsiregistruoti, duoti sutikimą bendrovei tvarkyti vartotojo duomenis (BDAR nuostatai). Dauguma bendrovių taiko amžiaus ribojimą potencialiems ir esamiems programos nariams. Prie programos norintis prisijungti fizinis asmuo turi būti bent 2, 12, 14 arba 16 metų amžiaus ir iki 18 metų privalo turèti tėvų ar globejjų sutikimą; turi būti bent 18 metų amžiaus. Kitos sąlygos - reikia būti tos oro linijos šalies nuolatiniu gyventoju; sumokèti mokestị (tik mokamose kasmetinėse programose); gauti individualų pakvietimą iš bendrovès; būti užsiregistravus „PINS“ programèlèje.

Kritiškai žvelgiant ị amžiaus ribojimo sąlygą, įdomu, kodèl bendrovès suteikia galimybes 2 metų vaikams prisijungti prie lojalumo programos. Akivaizdu, jog tokio amžiaus asmenys nesuvokia praktinès lojalumo programų prasmès ir patys, savo noru negali tapti lojaliais bendrovei. Tikètina, jog tėvai gali ,pasinaudoti“" savo vaikais ir per juos susikurti papildomą narystę bendroveje, tokiu būdu sukaupdami daugiau lojalumo taškų ir susidarydami galimybę atsiimti daugiau siūlomų naudų.

3 lentelè. Tyrimo duomenų suvestinè (parengta straipsnio autorių)

\begin{tabular}{|c|c|c|c|c|c|}
\hline \multirow[b]{2}{*}{ Bendrovè } & \multirow{2}{*}{$\begin{array}{l}\text { Lojalumo } \\
\text { programa }\end{array}$} & \multicolumn{4}{|c|}{ Prisijungimo sąlygos } \\
\hline & & Amžiaus riba & $\begin{array}{l}\text { Teritoriniai } \\
\text { apribojimai }\end{array}$ & Mokestis & Kitos sąlygos \\
\hline Swiss Air Lines & \multirow{6}{*}{ Miles ir More } & \multirow{6}{*}{ Ne mažiau 2 m. } & \multirow{6}{*}{$\begin{array}{l}\text { Vartotojas turi } \\
\text { būti tos šalies, } \\
\text { kurioje teikiama } \\
\text { lojalumo } \\
\text { programa, } \\
\text { gyventojas }\end{array}$} & \multirow{6}{*}{-} & \multirow{6}{*}{$\begin{array}{l}\text { Prisijungti gali tik } \\
\text { fizinis asmuo }\end{array}$} \\
\hline Lufthansa & & & & & \\
\hline Austrian Airlines & & & & & \\
\hline Eurowings & & & & & \\
\hline Brussels Airlines & & & & & \\
\hline $\begin{array}{l}\text { LOT Polish } \\
\text { Airlines }\end{array}$ & & & & & \\
\hline Ryanair & Ryanair Choice & - & - & $\begin{array}{l}199 €, \text { mokamas už } \\
\text { narystę kasmet }\end{array}$ & $\begin{array}{l}\text { Prisijungti gali tik } \\
\text { fizinis asmuo }\end{array}$ \\
\hline Aer Lingus & AerClub & Ne mažiau 18 m. & - & - & $\begin{array}{l}\text { Prisijungti gali tik } \\
\text { fizinis asmuo }\end{array}$ \\
\hline British Airways & Executive Club & Ne mažiau 18 m. & - & - & $\begin{array}{l}\text { Prisijungti gali tik } \\
\text { fizinis asmuo }\end{array}$ \\
\hline Iberia & \multirow{2}{*}{ Iberia Plus } & \multirow{2}{*}{$\begin{array}{l}\text { Ne mažiau } 2 \text { m., iki } \\
18 \text { m. reikalingas tèvų } \\
\text { sutikimas }\end{array}$} & \multirow{2}{*}{-} & \multirow{2}{*}{-} & \multirow{2}{*}{$\begin{array}{l}\text { Prisijungti gali tik } \\
\text { fizinis asmuo }\end{array}$} \\
\hline Level & & & & & \\
\hline Vueling & Vueling Club & - & - & - & $\begin{array}{l}\text { Prisijungti gali tik } \\
\text { fizinis asmuo }\end{array}$ \\
\hline
\end{tabular}


3 lentelès tęsinys

\begin{tabular}{|c|c|c|c|c|c|}
\hline \multirow[b]{2}{*}{ Bendrovė } & \multirow[b]{2}{*}{$\begin{array}{l}\text { Lojalumo } \\
\text { programa }\end{array}$} & \multicolumn{4}{|c|}{ Prisijungimo sąlygos } \\
\hline & & Amžiaus riba & $\begin{array}{l}\text { Teritoriniai } \\
\text { apribojimai }\end{array}$ & Mokestis & Kitos sąlygos \\
\hline Air France & \multirow{3}{*}{ Flying Blue } & \multirow{3}{*}{$\begin{array}{l}\text { Ne mažiau } 2 \text { m., iki } \\
18 \text { m. reikalingas tèvų } \\
\text { sutikimas }\end{array}$} & \multirow{3}{*}{$\begin{array}{l}\text { Vartotojas turi } \\
\text { būti tos šalies, } \\
\text { kurioje teikiama } \\
\text { lojalumo } \\
\text { programa, } \\
\text { gyventojas }\end{array}$} & \multirow{3}{*}{-} & \multirow{3}{*}{$\begin{array}{l}\text { Prisijungti gali tik } \\
\text { fizinis asmuo }\end{array}$} \\
\hline KLM & & & & & \\
\hline Transavia & & & & & \\
\hline \multirow[b]{2}{*}{ easyJet } & easyJet Plus & Ne mažiau 18 m. & - & $\begin{array}{l}252 €, \text { mokamas už } \\
\text { narystę kasmet }\end{array}$ & $\begin{array}{l}\text { Prisijungti gali tik } \\
\text { fizinis asmuo }\end{array}$ \\
\hline & Flight Club & - & - & - & $\begin{array}{l}\text { Prisijungti galima } \\
\text { tik su individualiu } \\
\text { bendrovės } \\
\text { pakvietimu }\end{array}$ \\
\hline Turkish Airlines & Miles\&Smiles & Ne mažiau 2 m. & - & - & $\begin{array}{l}\text { Prisijungti gali tik } \\
\text { fizinis asmuo }\end{array}$ \\
\hline $\begin{array}{l}\text { Aeroflot - } \\
\text { Russian Airlines }\end{array}$ & Aeroflot Bonus & Ne mažiau 12 m. & - & - & $\begin{array}{l}\text { Prisijungti gali tik } \\
\text { fizinis asmuo }\end{array}$ \\
\hline $\begin{array}{l}\text { Norwegian Air } \\
\text { Shuttle ASA }\end{array}$ & $\begin{array}{l}\text { Norwegian } \\
\text { reward }\end{array}$ & $\begin{array}{l}\text { Iki } 16 \mathrm{~m} \text {. reikalingas } \\
\text { tėvų sutikimas }\end{array}$ & - & - & $\begin{array}{l}\text { Prisijungti gali tik } \\
\text { fizinis asmuo }\end{array}$ \\
\hline Wizz Air & $\begin{array}{l}\text { WIZZ Discount } \\
\text { Club }\end{array}$ & - & - & $\begin{array}{l}39,99 € \text { vienam } \\
\text { nariui, arba } 79,99 € \\
6 \text { asmenų grupei, } \\
\text { mokamas kasmet }\end{array}$ & $\begin{array}{l}\text { Prisijungti gali tik } \\
\text { fizinis asmuo }\end{array}$ \\
\hline Pegasus Airlines & BolBol & $\begin{array}{l}\text { Ne mažiau } 2 \text { m., iki } \\
18 \text { m. reikalingas tèvų } \\
\text { sutikimas }\end{array}$ & - & - & $\begin{array}{l}\text { Prisijungti gali tik } \\
\text { fizinis asmuo }\end{array}$ \\
\hline $\begin{array}{l}\text { Scandinavian } \\
\text { Airlines }\end{array}$ & EuroBonus & $\begin{array}{l}\text { Iki } 18 \mathrm{~m} \text {. reikalingas } \\
\text { tėvų sutikimas }\end{array}$ & - & - & $\begin{array}{l}\text { Prisijungti gali tik } \\
\text { fizinis asmuo }\end{array}$ \\
\hline Alitalia & MilleMiglia & $\begin{array}{l}\text { Ne mažiau } 14 \text { m., iki } \\
18 \text { m. reikalingas tèvų } \\
\text { sutikimas }\end{array}$ & - & - & $\begin{array}{l}\text { Prisijungti gali tik } \\
\text { fizinis asmuo }\end{array}$ \\
\hline $\begin{array}{l}\text { TAP Air } \\
\text { Portugal }\end{array}$ & TAP Miles\&Go & Ne mažiau 2 m. & - & - & $\begin{array}{l}\text { Prisijungti gali tik } \\
\text { fizinis asmuo }\end{array}$ \\
\hline Aegean Airlines & Miles+Bonus & Ne mažiau 2 m. & - & - & $\begin{array}{l}\text { Prisijungti gali tik } \\
\text { fizinis asmuo }\end{array}$ \\
\hline Finnair & Finnair Plus & $\begin{array}{l}\text { Ne mažiau } 2 \text { m., iki } \\
17 \text { m. reikalingas tèvų } \\
\text { sutikimas }\end{array}$ & - & - & $\begin{array}{l}\text { Prisijungti gali tik } \\
\text { fizinis asmuo }\end{array}$ \\
\hline Jet2.com & myJet2 & Ne mažiau 18 m. & - & - & $\begin{array}{l}\text { Prisijungti gali tik } \\
\text { fizinis asmuo }\end{array}$ \\
\hline Air Europa & $\begin{array}{l}\text { Air Europa } \\
\text { SUMA }\end{array}$ & - & - & - & $\begin{array}{l}\text { Prisijungti gali tik } \\
\text { fizinis asmuo }\end{array}$ \\
\hline Flybe & - & - & - & - & - \\
\hline Smartwings & - & - & - & - & - \\
\hline $\begin{array}{l}\text { Ukraine } \\
\text { International } \\
\text { Airlines }\end{array}$ & Panorama Club & $\begin{array}{l}\text { Ne mažiau } 2 \text { m., iki } \\
\text { pilnametystès } \\
\text { reikalingas tėvų } \\
\text { leidimas }\end{array}$ & - & - & $\begin{array}{l}\text { Prisijungti gali tik } \\
\text { fizinis asmuo }\end{array}$ \\
\hline
\end{tabular}


3 lentelès pabaiga

\begin{tabular}{|c|c|c|c|c|c|}
\hline \multirow[b]{2}{*}{ Bendrovè } & \multirow{2}{*}{$\begin{array}{l}\text { Lojalumo } \\
\text { programa }\end{array}$} & \multicolumn{4}{|c|}{ Prisijungimo sąlygos } \\
\hline & & Amžiaus riba & $\begin{array}{l}\text { Teritoriniai } \\
\text { apribojimai }\end{array}$ & Mokestis & Kitos sąlygos \\
\hline Volotea & Megavolotea & $\begin{array}{l}\text { Iki } 18 \mathrm{~m} \text {. reikalingas } \\
\text { tėvų sutikimas }\end{array}$ & - & $\begin{array}{l}49,99 €, \text { mokamas } \\
\text { už narystę kasmet }\end{array}$ & $\begin{array}{l}\text { Prisijungti gali tik } \\
\text { fizinis asmuo }\end{array}$ \\
\hline $\begin{array}{l}\text { Virgin Atlantic } \\
\text { Airways Limited }\end{array}$ & Flying Club & $\begin{array}{l}\text { Iki } 18 \mathrm{~m} \text {. reikalingas } \\
\text { tėvų sutikimas }\end{array}$ & - & - & $\begin{array}{l}\text { Prisijungti gali tik } \\
\text { fizinis asmuo }\end{array}$ \\
\hline Icelandair & $\begin{array}{l}\text { Icelandair Saga } \\
\text { Club }\end{array}$ & $\begin{array}{l}\text { Ne mažiau } 12 \mathrm{~m} . \text {, iki } \\
18 \mathrm{~m} \text {. reikalingas tèvų } \\
\text { sutikimas }\end{array}$ & - & - & $\begin{array}{l}\text { Prisijungti gali tik } \\
\text { fizinis asmuo }\end{array}$ \\
\hline airBaltic & airBaltic Club & - & - & - & $\begin{array}{l}\text { Registracija } \\
\text { „PINS“ } \\
\text { programėleje }\end{array}$ \\
\hline
\end{tabular}

Lentelè parengta naudojantis informacija, pateikta oro linijų svetainèse (Aegean Airlines, 2019; Aer Lingus, 2018; Aeroflot, 2019; Air Europa, 2019; AirBaltic, 2019; Alitalia, 2018; British Airways, 2019; easyJet, 2019c, 2019a; Finnair, 2019; Flybe, 2019; Flying Blue, 2018; Iberia, 2019; Icelandair, 2019; Jet2, 2013; Miles ir More, 2017; Norwegian Air Shuttle ASA, 2020; Pegasus Airlines, 2019; Ryanair, 2019; Scandinavian Airlines, 2017; Smartwings, 2019; TAP Air Portugal, 2019; Turkish Airlines, 2019; Ukraine International Airlines, 2019; Virgin Atlantic, 2019; Volotea, 2019; Vueling, 2017; Wizz Air, 2019).

Gauti rezultatai atskleide kelis įdomius momentus apie didžiausiose Europos oro linijų bendrovèse taikomas lojalumo programų prisijungimo sąlygas. Pirmasis būtinasis reikalavimas - užsiregistravimas ị programą, sutinkant bendrovei pateikti savo duomenis bei sutinkant su jos numatytomis lojalumo programos taisyklèmis. Šị reikalavimą galutinai suformavo anksčiau straipsnyje minètas BDAR reglamentas. Antra sąlyga, būdinga visoms bendrovèms, yra leidimas dalyvauti programoje tik fiziniams asmenims. Tą galima logiškai paaiškinti - lojalumo programas siūlančios oro linijų bendrovės yra orientuotos ị pavienius, individualius vartotojus, jos teikia visuotines pervežimo oru paslaugas.

Analizè parodè, kad dauguma bendrovių yra nustačiusios amžiaus ribojimus asmenims, kurie gali prisijungti prie tam tikros lojalumo programos. Nustatyti skirtumai šiuo atžvilgiu tarp kai kurių lojalumo programų, pavyzdžiui, Flying Blue ir Miles\&Smiles. Flying Blue programos taisyklèse nurodomas konkretus prisijungimo amžius (ne jaunesni nei $2 \mathrm{~m}$.), tačiau taip pat pabrèžiama, jog tokio amžiaus nariams iki 18 metų yra būtinas jų tẻvų sutikimas dalyvavimui programoje. Programa Miles\&Smiles taip pat mini minimalų nario amžių (2 metus), tačiau neužsimena apie tẻvų sutikimą. Susidaro ịspūdis, kad bendrovè „Turkish Airlines“ mažamečius laiko galinčiais atsakyti už savo veiksmus, nors akivaizdu, jog tokio amžiaus žmogus savo noru niekaip lojalumo programos nariu netaptu.

Iš nagrinètų 33 lojalumo programų mokamų yra mažuma - tik 4. Visas jos yra pigių skrydžių bendrovių. Šioms bendrovèms jų mokamos lojalumo programos leidžia pritraukti didesnị vartotojų skaičiuu, išlaikant stabilias sąnaudas. Vis dèlto, dèl reto jų paplitimo daroma išvada, kad tradicinems oro linijoms vertingiau savo vartotojams siūlyti nemokamas, ịvairių tipų programas.

Bendrovè easyJet vienintelè iš visų didžiausių Europos oro linijų turi dvi vartotojo lojalumo programas. I vieną jų, easyJet Plus patekti nesunku, susimokẻjus metinị narystès mokestį. I kitą, Flight Club, patekti yra žymiai sudètingiau. Vartotojas savo iniciatyva ten patekti negali, jis gali tapti nariu tik bendrovei ji asmeniškai pakvietus. Tam, kad vartotojas turètų galimybę būti pakviestu, turi per metus su šia bendrove nuskristi bent 20 grižtamuju skrydžių (skrydžiai, kuriais ị kelionès tikslą ir atgal skrendama ta pačia kompanija). Galima teigti, kad gaunamas pakvietimas ị šią uždarą lojalumo programą ženkliai sustiprina vartotojo ir bendrovès ryšius ir lojalumą.

Apibendrinant atlikto tyrimo rezultatus, matyti, kad Europos aviacijos sektoriuje vartotoju lojalumo programos yra plačiai taikomos ir laikomos sèkminga marketingo priemone. Dauguma programų yra nemokamos, kas skatina vartotojus prisijungti prie programos ir gauti naudas tiesiog už ịprastą naudojimąsį bendrovès paslaugomis. Tik mažuma nagrinètų programų turi teritorinius apribojimus, tad praktiškai bet kuriam daug keliaujančiam pilnamečiam asmeniui dauguma Europos bendrovių lojalumo programų yra tinkamos prisijungti.

\section{Išvados}

1. Lojalumo programos per pastaruosius kelis dešimtmečius plačiai ir sparčiai išplito visame pasaulyje, kas rodo lojalumo programų poreikị ir potencialią naudą. Pagrindiné prisijungimo prie ịvairiuose sektoriuose veikiančiu lojalumo programų yra noras ir po to sekantis norą igyvendinantis veiksmas (lojalumo kortelès ịsigijimas, programèlès atsisiuntimas, nario paskyros sukūrimas ir t. t.). Analizè taip pat išryškino, kad prisijungimui prie lojalumo programų svarbus ir amžiaus kriterijus. 
2. Empirinio Europos oro linijų bendrovėse taikomų prisijungimo prie lojalumo programos sąlygų tyrimo rezultatai parodè, kad prisijungimo sąlygos, tikètina dèl didelių vartotojų srautų, yra labai paprastos. Neįmantriomis sąlygomis (taikant tam tikrus amžiaus apribojimus, kai kuriais atvejais ir teritorinius apribojimus ir/ar mokesčius už metinę narystę, elementarus užsiregistravimas lojalumo programoje, pavyzdžiui internete arba telefonu) siekiama paskatinti potencialius vartotojus pirkimams.

3. Tyrimu siekta sudaryti bendrą vaizdą apie didžiausias Europos oro linijų bendrovių lojalumo programas, sudaryti galimybę jas lyginti su kitų žemynų oro bendrovių ar kitų verslo sektorių lojalumo programomis. Remiantis gautais rezultatais teigiama, jog dažnai keliaujant oro transportu ir norint tapti lojaliu tam tikros oro bendrovės paslaugų vartotojų, tam oro linijų bendrovès sudaro visas sąlygas su aiškiai išdèstytais reikalavimais bei gaunamomis naudomis. Ateityje tyrimas gali būti plečiamas, analizuojant Artimųjų Rytų, įvairių Afrikos ar Azijos regionų oro linijas, jų siūlomas lojalumo programas bei prisijungimo sąlygas, jas vėliau lyginant su šio tyrimo rezultatais. Be to, galimas ir tyrimo objekto praplètimas, nagrinėjant apie vartotojus renkamą informaciją „,slapukais“, naudų gavimo pagrindus.

\section{Literatūra}

Aegean Airlines. (2019). Miles+Bonus terms and conditions. https://en.aegeanair.com/conditions-notices/milesbonus-termsand-conditions/

Aer Lingus. (2018). AerClub terms and conditions. https://www.aerlingus.com/localized/en/modals/aerclub-terms-andconditions.html

Aeroflot. (2019). Terms and conditions. https://www.aeroflot.ru/xx-en/afl_bonus/rules

Air Europa. (2019). Air Europa SUMA conditions. https://www.aireuropa.com/en/suma/conditions

Air France-KLM. (2019). Air France. https://www.airfranceklm.com/en/air-france

AirBaltic. (2019). About airBaltic Club. https://www.airbaltic.com/en/airbaltic-loyalty-club

Alitalia. (2018). Regulations of the edition of 1 January 2018 to 31 December 2019, extended to 31 December 2020. https://www.alitalia.com/en_gb/millemiglia/theprogram/rules/rules2020.html

American Airlines. (2019). AAdvantage terms and conditions. https://www.aa.com/i18n/aadvantage-program/aadvantageterms-and-conditions.jsp

Bombaij, N. J. F., \& Dekimpe, M. G. (2019). When do loyalty programs work? The moderating role of design, retailerstrategy, and country characteristics. International Journal of Research in Marketing, 37(1), 175-195. https://doi.org/10.1016/j.ijresmar.2019.07.003

Brashear-Alejandro, T., Kang, J., \& Groza, M. D. (2016). Leveraging loyalty programs to build customer-company identification. Journal of Business Research, 69(3), 1190-1198. https://doi.org/10.1016/j.jbusres.2015.09.014

Breugelmans, E., \& Liu-Thompkins, Y. (2017). The effect of loyalty program expiration policy on consumer behavior. Marketing Letters, 28, 537-550. https://doi.org/10.1007/s11002-017-9438-1

British Airways. (2019). Terms and conditions. https://www.britishairways.com/en-us/executive-club/terms-and-conditions

Chaudhuri, M., Voorhees, C. M., \& Beck, J. M. (2019). The effects of loyalty program introduction and design on short- and long-term sales and gross profits. Journal of the Academy of Marketing Science, 47, 640-658. https://doi.org/10.1007/s11747-019-00652-y

Colliander, J., Söderlund, M., \& Szugalski, S. (2016). Multi-level loyalty program rewards and their effects on top-tier customers and second-tier customers. Journal of Consumer Marketing, 33(3), 162-171. https://doi.org/10.1108/JCM-03-2015-1349

Cox, J. (2018). The year in aviation: Billions of passengers, two high-profile accidents. https://eu.usatoday.com/story/travel/columnist/cox/2018/12/26/aviation-review-record-number-passengersflights/2375060002/

de Jong, G., Behrens, C., \& van Ommeren, J. (2019). Airline loyalty (programs) across borders: A geographic discontinuity approach. International Journal of Industrial Organization, 62, 251-272. https://doi.org/10.1016/j.ijindorg.2018.02.005

Dorotic, M., Bijmolt, T. H. A., \& Verhoef, P. C. (2012). Loyalty programmes: Current knowledge and research directions. International Journal of Management Reviews, 14(3), 217-237. https://doi.org/10.1111/j.1468-2370.2011.00314.x

easyJet. (2019a). easyJet Flight Club - Terms and conditions. https://www.easyjet.com/en/terms-and-conditions/flight-club easyJet. (2019b). easyJet Plus card holder benefits. https://plus.easyjet.com/benefits.aspx

easyJet. (2019c). easyJet Plus membership terms and conditions. https://plus.easyjet.com/terms-and-conditions.aspx

Evanschitzky, H., Ramaseshan, B., Woisetschläger, D. M., Richelsen, V., Blut, M., \& Backhaus, C. (2012). Consequences of customer loyalty to the loyalty program and to the company. Journal of the Academy of Marketing Science, 40, 625638. https://doi.org/10.1007/s11747-011-0272-3

Finnair. (2019). Finnair Plus Rules. https://www.finnair.com/int/gb/finnair-plus/what-is-finnair-plus/rules

Flybe. (2019). Spend \& Fly has closed. https://www.flybe.com/spend-and-fly

Flying Blue. (2018). New terms and conditions. https://www.flyingblue.com/kamino/policies/en/fr 
Gambarov, V., Sarno, D., Hysa, X., Calabrese, M., \& Bilotta, A. (2017). The role of loyalty programs in healthcare service ecosystems. TQM Journal, 29(6), 899-919. https://doi.org/10.1108/TQM-02-2017-0019

Garzon, L., \& Taylor, D. C. (2016). Loyalty program in the alcohol beverage industry: A preliminary look. Atlantic Marketing Journal, 5(1), 89-105.

Hua, N., Wei, W., L. DeFranco, A., \& Wang, D. (2018). Do loyalty programs really matter for hotel operational and financial performance? International Journal of Contemporary Hospitality Management, 30(5), 2195-2213. https://doi.org/10.1108/IJCHM-12-2016-0643

IAG. (2019). Our brands. https://www.iairgroup.com/en/our-brands

Iberia. (2019). Iberia Plus programme general conditions. https://www.iberia.com/us/iberiaplus/conditions/

Icelandair. (2019). Conditions for Saga Club membership. https://www.icelandair.com/support/terms-andconditions/conditions-of-saga-club-membership/

IT Governance, \& European Union. (2017). EU General Data Protection Regulation (GDPR): An implementation and compliance guide (Second ed.).

Yoo, M. (Myongjee), Berezan, O., \& Krishen, A. S. (2018). Do members want the bells and whistles? Understanding the effect of direct and partner benefits in hotel loyalty programs. Journal of Travel and Tourism Marketing, 35(8), 10581070. https://doi.org/10.1080/10548408.2018.1473191

Jet2. (2013). Terms and conditions. https://www.jet2.com/myjet2terms

Koo, B., Yu, J., \& Han, H. (2020). The role of loyalty programs in boosting hotel guest loyalty: Impact of switching barriers. International Journal of Hospitality Management, 84, 102328. https://doi.org/10.1016/j.ijhm.2019.102328

Lo, A. S., Im, H. H., Chen, Y., \& Qu, H. (2017). Building brand relationship quality among hotel loyalty program members. International Journal of Contemporary Hospitality Management, 29(1), 458-488. https://doi.org/10.1108/IJCHM-062015-0283

Lufthansa Group. (2019). Business segments. https://www.lufthansagroup.com/en/company/business-segments.html

Marriott. (2019). Loyalty program terms \& conditions. https://www.marriott.com/loyalty/terms/default.mi

Martín, J. C., Román, C., \& Espino, R. (2011). Evaluating frequent flyer programs from the air passengers' perspective. Journal of Air Transport Management, 17(6), 364-368. https://doi.org/10.1016/j.jairtraman.2011.02.008

MGM Resorts. (2019). Yes, there are a few rules to follow. https://www.mgmresorts.com/en/mlife-rewardsprogram/program-rules.html

Miles \& More. (2017). Miles \& More terms and conditions of participation. https://www.miles-andmore.com/row/en/general-information/terms-and-conditions/terms-and-conditions-detailpage.html

Mimouni Chaabane, A., \& Pez, V. (2017). "Make me feel special": Are hierarchical loyalty programs a panacea for all brands? The role of brand concept. Journal of Retailing and Consumer Services, 38, 108-117. https://doi.org/10.1016/j.jretconser.2017.05.007

Nastasoiu, A., \& Vandenbosch, M. (2019). Competing with loyalty: How to design successful customer loyalty reward programs. Business Horizons, 62(2), 207-214. https://doi.org/10.1016/j.bushor.2018.11.002

Norwegian Air Shuttle ASA. (2020). Terms and conditions. https://en.norwegianreward.com/about-us/terms-and-conditions

Pegasus Airlines. (2019). General terms \& conditions. https://www.flypgs.com/en/useful-info/info-about-flights/generalrules

REI. (2019). Terms of use. https://help.rei.com/app/answers/detail/a_id/51/ /terms-of-use

Ryanair. (2019). Ryanair customer care improvements 2019. https://www.ryanair.com/try-somewhere-new/gb/en/traveltips/customer-care-improvements-2019/

Scandinavian Airlines. (2017). EuroBonus terms and conditions. https://www.sas.no/reiseinfo/villkar-ogbetingelser/eurobonus-terms-conditions/

Sephora. (2019). Beauty insider terms \& conditions. https://www.sephora.com/beauty/terms-conditions-beauty-insider

Skačkauskienė, I. ir Vilkaitè-Vaitonè, N. (2017). Paslaugu vartotojų lojalumas: Monografija. https://doi.org/10.20334/2017-058-M

Smartwings. (2019). About Smartwings. https://www.smartwings.com/en/about-smartwings

So, J. T., Danaher, T., \& Gupta, S. (2015). What do customers get and give in return for loyalty program membership? Australasian Marketing Journal, 23(3), 196-206. https://doi.org/10.1016/j.ausmj.2015.02.002

Starbucks. (2019). Starbucks rewards terms of use. https://www.starbucks.com/rewards/terms

Statista. (2018). Global No. 1 business data platform. https://www.statista.com/

TAP Air Portugal. (2019). Terms and conditions - TAP Miles\&Go programme. https://www.flytap.com/en-us/terms-andconditions-miles-and-go?accordionid=1

Turkish Airlines. (2019). Terms and conditions. https://www.turkishairlines.com/en-int/miles-and-smiles/terms-andconditions/

Ukraine International Airlines. (2019). Panorama Club terms and conditions. https://www.flyuia.com/lt/en/panoramaclub/terms-conditions-pc-new

Virgin Atlantic. (2019). Virgin Atlantic Flying Club terms and conditions. https://www.virginatlantic.com/za/en/footer/termsand-conditions/flying-club.html

Volotea. (2019). Terms of use. https://www.volotea.com/en/legal-conditions/terms-of-use/ 
Vueling. (2017). Vueling Club programme terms and conditions. https://www.vueling.com/en/vueling-club/vueling-clubprogramme-terms-and-conditions

Wizz Air. (2019). Wizz Discount Club terms and conditions. https://wizzair.com/static/docs/default-source/downloadabledocuments/wizz-discount-club-terms-and-conditions_final_no_trial_fbfcc037.pdf

\title{
CUSTOMERS ENROLLMENT IN LOYALTY PROGRAMS OF THE LARGEST EUROPEAN AIRLINES TERMS AND CONDITIONS
}

\author{
Neringa VILKAITĖ-VAITONĖ, Vytenis ŠALKAUSKIS
}

\begin{abstract}
The article is aimed to analyse the customer loyalty programs in airline industry. General definition of loyalty programs is given, diverse program types and the terms and conditions to enroll in them are reviewed. Used methods: scientific literature analysis and comparative analysis. The main goal is stated - to analyse the situation regarding customer loyalty programs in the largest European airlines. The main scope of this paper is aimed towards the largest European airlines loyalty programs distribution, their types and the conditions to enroll in them. Used method - content analysis. The research revealed that almost every airline in the list offers some kind of loyalty program, of which majority are hierarchical type. Research also revealed that the leading terms and conditions to enroll in the loyalty programs are member age limitation and their status (only natural people are allowed to join the programs). This brings to a conclusion that airlines treat customers responsibly and estimate their tendency to remain loyal for longer periods while reaching higher program levels.
\end{abstract}

Keywords: loyalty programs, terms and conditions to enroll in the program, largest European airlines, loyalty programs customers, aviation industry, types of loyalty programs. 